(C) 1982. The Genetical Society of Great Britain

\title{
GENETIC INSTABILITY AT THE S-LOCUS OF LYCOPERSICON PERUVIANUM PLANTS REGENERATED FROM IN VITRO CULTURE OF ANTHERS: GENERATION OF NEW S-SPECIFICITIES AND S-ALLELE REVERSIONS
}

\author{
K. SREE RAMULU \\ Research Institute ITAL, Mail box 48, 6700 AA Wageningen, The Netherlands \\ Received 30.vi.82
}

\section{SUMMARY}

\begin{abstract}
Genetic analyses were made of plants regenerated from in vitro cultures of anthers and stem internodes in four different self-incompatible diploid genotypes of Lycopersicon peruvianum. Altogether 9 diploids, 15 tetraploids and 3 cytochimeric plants regenerated from stem internode cultures and 35 diploids, 10 tetraploids and 9 cytochimeras derived from anther culture, were analysed.

The plants regenerated from stem internode cultures had no alterations at the $S$-locus, whereas a high proportion of anther culture-derived regenerants carried sexually heritable changes, namely new $S$-specificities and $S$-allele reversions, the reverted $S$-allele showing a switch from gametophytic to sporophytic expression.
\end{abstract}

\section{INTRODUCTION}

WHEN nonmeristematic tissue explants or single cells are cultured in vitro, they display genetic instabilities of various kinds. These can occur at the time of callus induction and/or during further growth in vitro. Several factors appear to be associated with the degree of instability (D'Amato, 1975, 1977, 1978; Sunderland, 1977; Skirvin, 1978; Thomas et al., 1979; Cappadocia and Sree Ramulu, 1981).

Many examples of genetic variability generated by plant cell cultures (somaclonal variation) have been discussed by Larkin and Scowcroft (1981). A majority of these deal with the occurrence of polyploidy, aneuploidy, chromosome number mosaicism and structural changes in cultures of cells, protoplasts or tissues, and in generated plants. In addition, some reports have appeared on the incidence of somatic mutations at loci affecting chlorophyll synthesis (reversion to a wild type allele or deletion) (Barbier and Dulieu, 1980), mitochondrial DNA variation (Gengenbach et al., 1981) and sexually heritable changes in agronomic characters, such as yield, plant height, heading date, leaf characters, fertility, etc. (Mousseau, 1970; Popchristov and Zaganska, 1977; Cummings et al., 1976; Oono, 1978).

The homomorphic gametophytic incompatibility system in Lycopersicon peruvianum is controlled by multiple alleles ( $S$-alleles) at one locus (Lamm, 1950; McGuire and Rick, 1954; Gunther et al., 1968). It has been proposed that the $S$-locus in monofactorial gametophytic systems has a tripartite structure: two parts controlling the reaction in the pollen and in the style, respectively, and one part common to both pollen and style which determines the specificity (Lewis, 1949, 1960). These parts of the S-locus are 
apparently mutationally independent and functionally integrated (Lewis, 1951, 1958; Lewis and Crowe, 1954; Pandey, 1956). Thus, the identification of three distinct parts in the $S$-locus and the independent mutability of each of these parts provide valuable material for analysing the processes of gene regulation, metabolic pathways and their relationships to gene structure and gene mutation. In addition, $L$. peruvianum is an important species for tomato breeding, especially for disease resistance. Accordingly, several previous studies have been carried out with this species using in vitro culture techniques in order to investigate certain problems related to incompatibility (Devreux et al., 1975; Sree Ramulu et al., $1976 a, b$; Ancora et al., 1977; Ancora and Sree Ramulu, 1981). In an earlier investigation on in vitro cultures of anthers and stem internodes of different self-incompatible diploid genotypes in $L$. peruvianum (Sree Ramulu et al., 1976a), not only diploids, but also tetraploids and cytochimeras were regenerated.

The present study examines the occurrence, type and extent of genetic changes at the $S$-locus of these regenerated plants and explains the mechanism of origin of $S$-allele alterations.

\section{MAterial AND METHODS}

\section{(i) Plant material}

Plants regenerated in vitro from anther cultures of clones $9-S_{1}^{\prime} S_{3}$ and F13- $S_{12} S_{13}$ and from the stem internode cultures of P20-S $S_{5}$ and F9- $S_{4} S_{5}$ of Lycopersicon peruvianum Mill. $(2 \mathrm{n}=24)$ (Sree Ramulu et al., 1976a) were used in this study. Genetic analyses indicated that the genetic architecture of the $S_{1}^{\prime}$ allele of clone $9-S_{1}^{\prime} S_{3}$ is different from that of $S_{1}$ of clone $1-S_{1} S_{1}$. The details are later given in Results.

Table 1 gives details on the frequency and type of plants analysed in each of the clones. For details on in vitro culture procedures and cytological techniques, reference is made to Sree Ramulu et al. $(1976 \mathrm{a}, 1977)$. The plants were grown under controlled conditions $\left(16 \mathrm{~h}\right.$ day, $13000 \mathrm{~lx}, 23^{\circ} \mathrm{C}$; $8 \mathrm{~h}$ night, $17^{\circ} \mathrm{C}$, relative humidity $60-70$ per cent).

\section{(ii) Pollination procedures}

Self- and cross-pollinations were performed in strict isolation for the detection of changes at the $S$-locus of regenerated plants. The plants were selfed manually, and in all the experiments self-pollinations and crosses between two individuals were made on 10-20 or more flowers, preferably at two different periods in the life cycle of the plants.

The progeny tests were made to ascertain the transmissibility of altered $S$-alleles and their functional behaviour in pollen and style. Several testerstocks were used for determining $S$-genotypes: $S_{1} S_{1}, S_{2} S_{2}, S_{2} S_{3}, S_{1} S_{4}, S_{2} S_{4}$, $S_{2} S_{5}, S_{1} S_{6}, S_{2} S_{6}, S_{1} S_{7}, S_{2} S_{7}$, and $S_{6} S_{7}$.

Observations on pollen tube growth in styles of pollinated flowers were made by fluorescent microscopy (Martin, 1958). Wherever necessary, the data on fruit- and seed-set were supplemented by observations on pollen tube growth. Pollen abortion was ascertained by staining tests with acetocarmine. 


\section{RESUlts}

(i) Analysis of plants regenerated from stem internode cultures of clones $\mathrm{P}_{20}-\mathrm{S}_{1} \mathrm{~S}_{5}$ and $\mathrm{F}_{9}-\mathrm{S}_{4} \mathrm{~S}_{5}$

Altogether 15 tetraploids, 9 diploids and 3 cytochimeras $(4 n-2 n-2 n)$ were analysed (table 1). The data on fruit- and seed-set after self-pollinations, and test-crosses with the respective mother clones showed that no alterations occurred at the $S$-locus of the diploids and cytochimeric regenerants (table 2). The testing at tetraploid level for altered $S$-alleles requires several tester-stocks with all necessary combinations of $S$-alleles. The data in table 2 can only reveal the compatibility behaviour, but not altered $S$-alleles. As can be seen from the results, all the tetraploids behaved as normal autotetraploids with regard to compatibility.

TABLE 1

Types of plants regenerated from in vitro cultures of anthers and stem internodes in selfincompatible diploid genotypes of Lycopersicon peruvianum $(2 n=24)$

\begin{tabular}{|c|c|c|c|c|}
\hline \multirow{2}{*}{ Genotypes } & \multirow[b]{2}{*}{ Diploids } & \multirow[b]{2}{*}{ Tetraploids } & \multicolumn{2}{|c|}{ Cytochimeras* } \\
\hline & & & $4 n-2 n-2 n$ & $2 n-4 n-4 n$ \\
\hline \multicolumn{5}{|l|}{ Anther culture } \\
\hline $9-S_{1}^{\prime} S_{3}$ & 32 & 0 & 5 & 1 \\
\hline $\mathrm{F} 13-S_{12} S_{13}$ & 3 & 10 & 3 & 0 \\
\hline \multicolumn{5}{|l|}{ Stem internode culture } \\
\hline $\mathbf{P} 20-S_{1} S_{5}$ & 0 & 7 & 1 & 0 \\
\hline $\mathrm{F} 9-S_{4} S_{5}$ & 9 & 8 & 2 & 0 \\
\hline
\end{tabular}

TABLE 2

Compatibility behaviour after self-pollinations and test-crosses of plants regenerated from the stem internode cultures of clones $\mathrm{P2O}-\mathrm{S}_{1} \mathrm{~S}_{5}$ and $\mathrm{F}_{-}-\mathrm{S}_{4} \mathrm{~S}_{5}$

\begin{tabular}{|c|c|c|c|c|c|}
\hline & & & & & \\
\hline & & & & $q$ & $\delta$ \\
\hline & Regeneratec & & & $x$ & $x$ \\
\hline Clone & Type & No. & Self-pollinations & Par & lone \\
\hline $\mathrm{P} 20-S_{1} S_{5}$ & Tetraploid & 7 & + & - & + \\
\hline & $\begin{array}{l}\text { Cytochimeras } \\
(4 n-2 n-2 n)\end{array}$ & 1 & - & - & - \\
\hline$F 9-S_{4} S_{5}$ & Tetraploid & 8 & + & - & + \\
\hline & Diploid & 9 & - & - & - \\
\hline & $\begin{array}{l}\text { Cytochimeras } \\
(4 n-2 n-2 n)\end{array}$ & 2 & - & - & - \\
\hline
\end{tabular}

(ii) Analysis of plants regenerated from anther cultures of clone 9-S $\mathrm{S}_{1}^{\prime} \mathrm{S}_{3}$

(a) First generation plants

In all, 32 diploids and 6 cytochimeric plants were analysed. In 5 cytochimeric plants of type $4 n-2 n-2 n$ (tables 1 and 3 ) the tetraploid $L_{1}$ layer had no influence on seed-set, as verified by test-crosses with crosscompatible tetraploids. The remaining plant with $2 n-4 n-4 n$ condition behaved like a normal autotetraploid (self-compatible) (date not given in table 3). As can be seen from the data on fruit and seed yields presented 


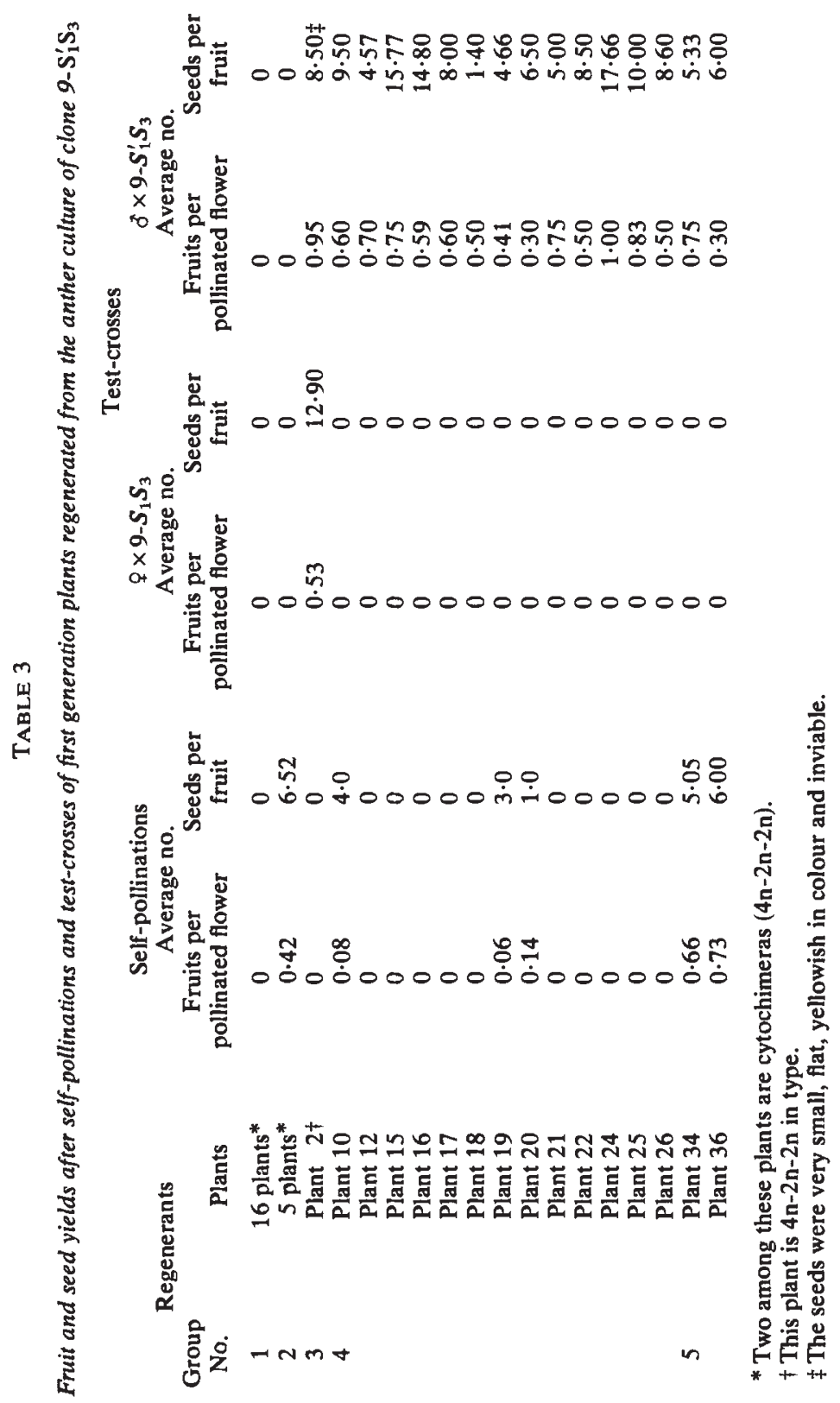


in table 3, not a single case of (viable) fruit-set occurred in 16 (group 1) out of 37 regenerants after self-pollinations, or test-crosses with the parental clone $\left(9-S_{1}^{\prime} S_{3}\right)$ indicating that no changes were generated at the $S$-locus. These plants had high male and female fertility as determined by tests on pollen staining and tube growth in styles, and fruit- and seed-set after crosses with tester-stocks.

Five other regenerants (group 2) gave relatively high fruit-set and regular seed-set after self-pollinations, but the reciprocal crosses with the parental clone $9-S_{1}^{\prime} S_{3}$ were incompatible. The analyses of 125 progeny plants derived from the selfed seeds showed that all were self-incompatible and cross-incompatible with $9-S_{1}^{\prime} S_{3}$, thus indicating that these regenerants displayed "pseudo self-compatibility".

The fruit- and seed-set data of the remaining 16 regenerated plants showed that 15 (group No. 4 and 5) set seed when crossed as males and 1 (plant 2 of group 3 ) when used as a female also with $9-S_{1}^{\prime} S_{3}$, (table 3 ). Besides showing cross-compatibility as pollen parents with $9-S_{1}^{\prime} S_{3}$, plants No. 34 and 36 (group 5) gave relatively high fruit-set and regular seed-set after self-pollinations. All the plants had high pollen and ovule fertility as verified by crosses with cross-compatible tester-stocks. They were also normal in karyotype and meiotic behaviour. These results, thus indicate that alterations occurred at the $S$-locus of regenerated plants and that they are expressed only in the pollen of 15 regenerants, and both in the pollen and pistil of one regenerant (plant 2).

\section{(b) Second and third generation plants}

In order to ascertain the nature of these changes, their transmissibility and their functional behaviour in pollen and style, the progenies that were obtained from 12 different crosses between $9-S_{1}^{\prime} S_{3}$ and regenerated plants were analysed. Besides self-pollinations, reciprocal crosses were performed with $9-S_{1}^{\prime} S_{3}$ (table 4 ). The results showed that all of the 112 progeny were

TABLE 4

Compatibility behaviour after self-pollinations and test-crosses of the second generation progeny

9-S $S_{1}^{\prime} S_{3}$ $\times$ plant 24

$9-S_{1}^{\prime} S_{3} \uparrow \times$ plant 15

$9-S_{1}^{\prime} S_{3}$ \& $\times$ plant 16

9- $S_{1}^{\prime} S_{3}+\times$ plant 17

$9-S_{1}^{\prime} S_{3} q \times$ plant 22

$9-S_{1}^{\prime} S_{3}$ $\$ \times$ plant 34

9- $S_{1}^{\prime} S_{3}$ $\$ \times$ plant 19

$9-S_{1}^{i} S_{3} \uparrow \times$ plant 26

9- $S_{1}^{\prime} S_{3}$ \& $\times$ plant 18

9- $S_{1}^{\prime} S_{3}+\times$ plant 21

9- $S_{1}^{\prime} S_{3}+\times$ plant 25

Plant $2 \uparrow \times 9-S_{1}^{\prime} S_{3}$

No. of
progeny
analysed
9
8
20
14
12
13
6
7
5
4
4
10

* Two progeny plants were sterile.

$\dagger$ One progeny plant was sterile.

- Cross-incompatible.

+ Cross-compatible (in almost all cases $>20$ seeds/fruit).

\begin{tabular}{ccc} 
Self- & \multicolumn{2}{c}{ Test-crosses } \\
pollinations & $+\times 9-S_{1}^{\prime} S_{3}$ & $\delta \times 9-S_{1}^{\prime} S_{3}$ \\
- & + & $+^{*}$ \\
- & + & $+^{*}$ \\
- & + & + \\
- & + & $+\dagger$ \\
- & + & $+^{*}$ \\
- & + & $+{ }^{*}$ \\
- & + & + \\
- & + & + \\
- & + & + \\
- & + & + \\
- & + & $+\dagger$
\end{tabular}


both self-incompatible, and reciprocally cross-compatible with $9-S_{1}^{\prime} S_{3}$, which indicate that these changes are heritable.

Further, in order to determine the $S$-genotypes in pollen and styles, some progeny plants selected from each of 7 different crosses between $9-S_{1}^{\prime} S_{3}$ and the regenerants, were analysed. These test-crosses were performed with tester-stocks $S_{1} S_{1}, S_{2} S_{2}, S_{1}^{\prime} S_{3}$ and $S_{2} S_{3}$. It can be seen from the data in table 5 that a new allele, namely $S_{2}^{*}$ occurred in pollen and styles of all 63 progeny plants. Further, the data on $S$-genotypes in pollen and styles of the third generation progeny (table 6) confirm the transmissibility and stability of the new $S_{2}^{*}$ allele. It should be mentioned here that the clone $9-S_{1}^{\prime} S_{3}$ used in this study has been obtained previously after inbreeding of clone 006-S $S_{1} S_{2}$, the $S_{3}$ being derived from $S_{2}$ (de Nettancourt et al. $1971,1975)$. The occurrence of a new $S_{2}^{*}$ allele in the plants regenerated from the anther culture of $9-S_{1}^{\prime} S_{3}$ indicates that the $S_{3}$ allele reverted to a new $S_{2}^{*}$ allele.

\section{(c) Sporophytic action of new $\mathrm{S}_{2}^{*}$ allele}

The progenies of crosses between regenerants carrying the new $S_{2}^{*}$ allele and the parental clone $9-S_{1}^{\prime} S_{3}$ regularly segregated as $1 \times S_{2}^{*} S_{2}^{*}$ : $1 \times S_{2}^{*} S_{3}$ instead of the expected $1 \times S_{1}^{\prime} S_{2}^{*}: 1 \times S_{2}^{*} S_{3}$ (tables 5 and 6). This suggests that the new $S_{2}^{*}$ allele is dominant over the $S_{1}^{\prime}$ allele of clone $9-S_{1}^{\prime} S_{3}$ and that plants of $S_{2}^{*}$ phenotype are of $S_{1}^{\prime} S_{2}^{*}$ genotype. This type of switch from gametophytic to sporophytic action of the $S_{2}^{*}$ allele is transmitted from one generation to the other.

\section{(d) Difference between $\mathrm{S}_{1}^{\prime}$ allele of clone $9-\mathrm{S}_{1}^{\prime} \mathrm{S}_{3}$ and $\mathrm{S}_{1}$ of clone $1-\mathrm{S}_{1} \mathrm{~S}_{1}$}

The new $S_{2}^{*}$ allele shows no dominance over the $S_{1}$ allele of clone $1 \times S_{1} S_{1}$. The test crosses indicate that when $1 \times S_{1} S_{1}$ is crossed with plants stabilized for the new $S_{2}^{*}$ specificity, i.e., $S_{2}^{*} S_{3}$ genotype, or plants of $S_{2}^{*}$ phenotype $\left(S_{1}^{\prime} S_{2}^{*}\right.$ genotype), the progeny segregated approximately as $1 \times S_{1} S_{2}^{*}: 1 \times S_{1} S_{3}$, or $1 \times S_{1} S_{1}^{\prime}: 1 \times S_{1} S_{2}^{*}$, but contained no $S_{2}^{*}$ phenotype. Thus, it appears that the $S_{1}$ allele of clone $1-S_{1} S_{1}$ is different from that of clone $9-S_{1}^{\prime} S_{3}$. As the clone $9-S_{1}^{\prime} S_{3}$ has previously been obtained after inbreeding of clone $006-S_{1} S_{2}$ (de Nettancourt et al., 1971), it is likely that, besides the generation of $S_{3}$, some change might have occurred in the $S_{1}^{\prime}$ allele. Therefore, it is probable that the genetic architecture of the $S_{1}^{\prime}$ allele of clone $9-S_{1}^{\prime} S_{3}$ is different from that of $S_{1}$ of clone $1-S_{1} S_{1}$.

\section{(iii) Analysis of plants generated from anther culture of clone F13- $\mathrm{S}_{12} \mathrm{~S}_{13}$}

The results of self-pollinations and test-crosses with the parental clone F13- $S_{12} S_{13}$ show that among the ten tetraploids, nine behaved as normal autotetraploids with regard to compatibility (table 7). The other tetraploid was not only self-incompatible, but also cross-incompatible as male with F13- $S_{12} S_{13}$ as determined from fruit- and seed-set and pollen tube growth. The pollen abortion was 90 per cent. However, test-crosses with crosscompatible tetraploids reveal that this plant was both male and female fertile. These results indicate that the self-incompatibility in this tetraploid is due to the $S$-homozygous condition (quadruplex: $S_{12} S_{12} S_{12} S_{12}$ or 

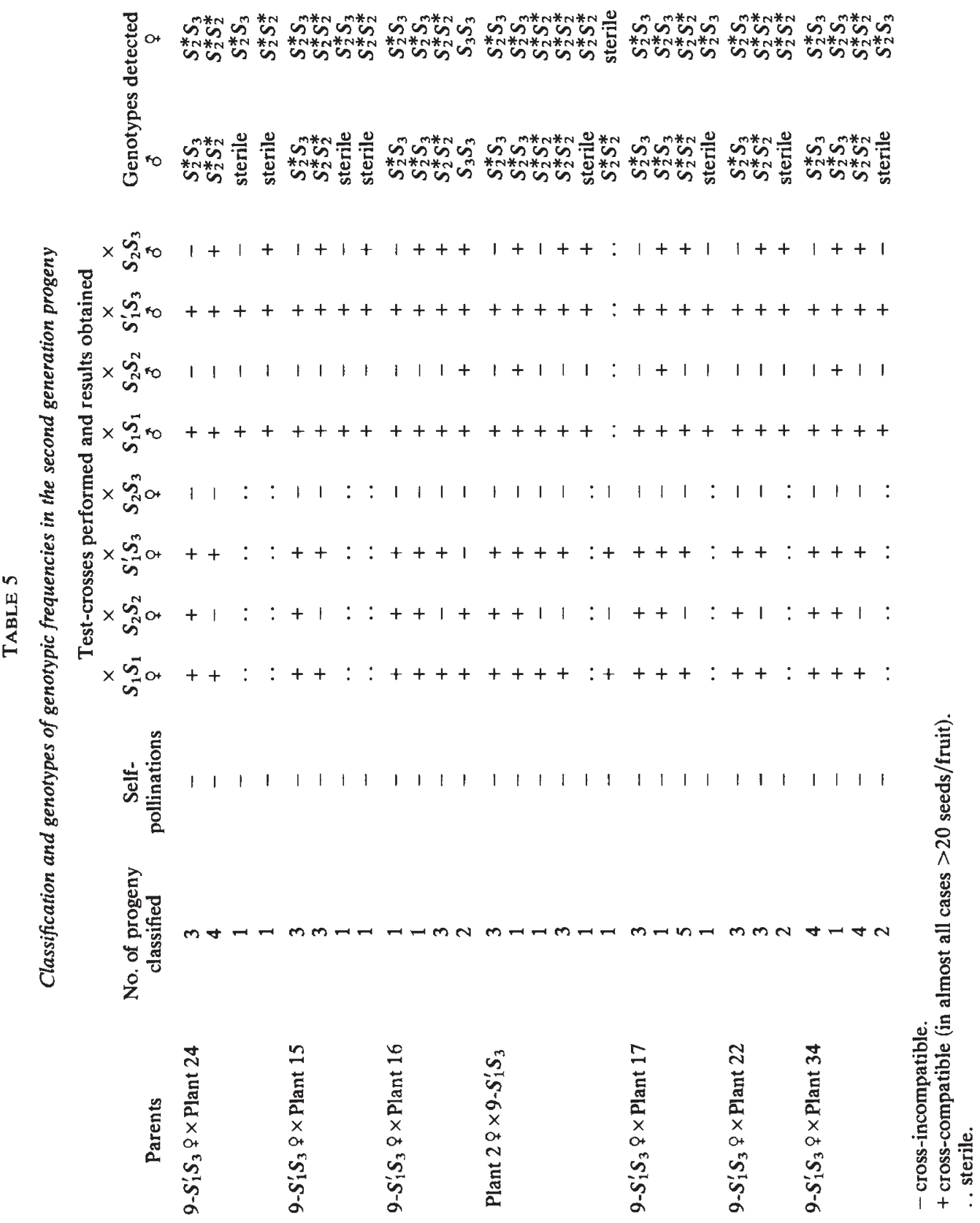


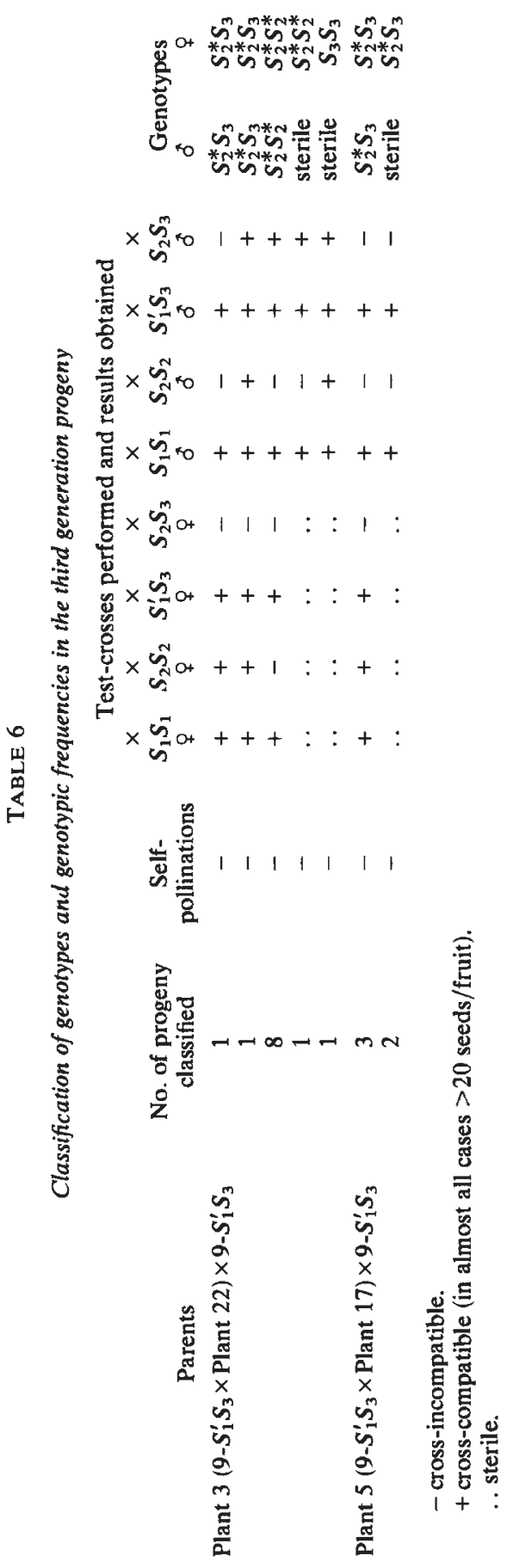




\section{TABLE 7}

Compatibility behaviour after self-pollinations and test-crosses of plants regenerated from the anther culture of clone $F 13-S_{12} S_{13}$

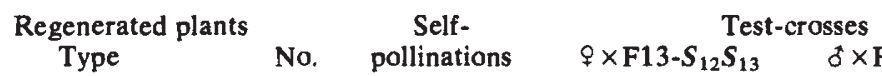

$\begin{array}{lllll}\text { Tetraploid } & 9 & + & - & + \\ \text { Tetraploid } & 1 & - & + & - \\ \text { Diploid } & 2 & - & - & + \\ \text { Diploid (Plant 15) } & 1 & - & - & - \\ \text { Cytochimeras (4n-2n-2n) } & 3 & - & - & \\ \quad \text { - compatible. } & & & & \\ \quad \text { incompatible. } & & & \end{array}$

$\left.S_{13} S_{13} S_{13} S_{13}\right)$. The abnormal morphological features expressed by vegetative and floral parts and the reduced vigour and fertility seem to be associated with the homozygous condition.

Among the other regenerated plants, only one plant, i.e., plant 15 showed cross-compatibility as male with F13-S $S_{12} S_{13}(0 \cdot 8$ fruits/flower and $12.3 \mathrm{seeds} /$ fruit) (table 7). The results of the analysis of 17 progeny plants obtained from crosses between plant $15\left({ }^{*}\right)$ and $F 13-S_{12} S_{13}$ show that all were selfincompatible and reciprocally cross-compatible with F13- $S_{12} S_{13}$. Plant 15 as well as its progeny were normal in karyotype and meiotic behaviour. These results indicate that in plant 15 a new $S$-specificity was generated which expressed itself in the pollen in the first generation and was then transmitted to progeny where it stabilized both in the pollen and pistil.

The new $S$-allele was cross-compatible with all the diploid tester-stocks of $L$. peruvianum ( $S_{1}$ to $S_{13}$ alleles) available at our institute.

\section{4. ' Discussion}

The results obtained in the present study show that many of the regenerants ( 16 out of 38 plants) from the anther culture of clone $9-S_{1}^{\prime} S_{3}$ carried a heritable change at the $S$-locus. The testing of $S$-genotypes performed for three generations in order to determine the type of $S$-gene alterations in the regenerants revealed the following features.

(a) All the 16 regenerants carried a new $S_{2}^{*}$ allele.

(b) The $S_{3}$ allele of the parental clone $9-S_{1}^{\prime} S_{3}$ reverted to a new $S_{2}^{*}$ allele.

(c) The new $S_{2}^{*}$ allele is dominant over $S_{1}^{\prime}$ allele of clone $9-S_{1} S_{3}$, and this switch from gametophytic to sporophytic action is heritable.

Extensive studies with radiations and chemical mutagens have shown that none generated new $S$-alleles (Lewis, 1949, 1951; Lewis and Crowe 1954; Pandey, 1956, 1965; Brewbaker and Natarajan 1960; de Nettancourt and Ecochard, 1968; Hoffman, 1971; van Gastel and de Nettancourt, 1974, 1975 ), thus suggesting that new $S$-specificities probably do not result from point mutations at the $S$-locus (see Sree Ramulu, 1980). Inbreeding, the only method which so far has generated new $S$-alleles leads to some processes which result under favourable conditions in the generation of new $S$-specificities (Denward, 1963; de Nettancourt and Ecochard, 1969; 
de Nettancourt et al., 1971; Pandey, 1970a, 1972, 1977; Hogenboom, 1972; Anderson et al., 1974; Sree Ramulu, 1982). The $S$-alleles are stable under the conditions of a relatively high degree of heterozygosity and the $S$-allele dependent polygenic system is presumably drastically modified by inbreeding.

Fisher (1961) formulated a hypothesis of new $S$-allele generation through recombination between two parental allele complexes. This hypothesis has been elaborated by Lewis (1962) and discussed by Lundqvist (1965) and Pandey (1970b). In previous studies on the generation of new $S$-alleles by inbreeding in $L$. peruvianum, de Nettancourt (1977) also discussed the implications of Fisher's model in relation to the rare cases of reversion of the $S_{3}$ allele to $S_{2}$. These occurred among the progeny of crosses between the inbred plants stabilized for the new $S$-specificity $\left(S_{2} S_{3}\right.$ or $\left.S_{1} S_{3}\right)$ and the original clone $\left(S_{1} S_{2}\right)$ (see de Nettancourt et al. 1971, 1975). According to the model, the new $S$-specificity generated through recombination would not be able to bring about compatibility on selfing and remains incompatible to each of the two parental alleles. The recombinant allele produces a mixture of the two parental antigens and leads to cross-reactions with the pistil containing both original alleles. However, if the new $S$-allele produces a qualitatively different antigen from the two parental alleles, it can bring about compatibility on selfing. The various $S$-alleles considered as identical and classified within the same group may, in fact, be genetically different. The reversions can occur through recombination and the reverted allele need not be similar in structure to the parental allele, but can simply display an identical phenotype.

The results obtained in the present study on the features characterizing the new $S_{2}^{*}$ specificity produced in plants regenerated from anther culture of clone $9-S_{1}^{\prime} S_{3}$, seem to fit with this hypothesis.

(a) The new $S_{2}^{*}$ allele is presumably different in structure from that of its ancestral allele $S_{2}$.

(b) The new $S_{2}^{*}$ expressed in the pollen of regenerants of group 4 was not able to bring about compatibility on selfing. The same appears to be true in plant 15 regenerated from the anther culture of clone F13- $S_{12} S_{13}$ in which a new $S$-specificity expressed in the pollen could not bring about self-compatibility.

(c) However, in two plants (group 5) regenerated from clone $9-S_{1}^{\prime} S_{3}$, the new $S_{2}^{*}$ expressed in pollen could bring about moderate selfcompatibility. The progeny obtained from selfed seeds segregated approximately as $1 \times S_{2}^{*} S_{2}^{*}: 1 \times S_{2}^{*} S_{3}$ as did the progeny from crosses between the regenerants $\left(\delta^{*}\right)$ and the parental clone $9-S_{1}^{\prime} S_{3}$.

The possibility that the regenerants carrying the new $S_{2}^{*}$ allele originated from microspore (or pollen)-derived calli can not be excluded.

Acknowledgements. - The author is grateful to Prof D. de Nettancourt and Prof. M. Devreux for their warm encouragement and useful suggestions during the course of this investigation, and to Prof J. H. van der Veen and Prof J. Sybenga for stimulating discussions and valuable comments in the preparation of the manuscript. Sincere thanks are also due to Mr P. Dijkhuis for his excellent technical assistance. 


\section{REFERENCES}

ANCORA, G., AND SREe RAMULU, K. 1981. Plant regeneration from in vitro cultures of stem internodes in self-incompatible triploid Lycopersicon peruvianum Mill. and cytogenetic analysis of regenerated plants. Plant Sci. Lett., 22, 197-204.

ANCORA, G., SREE RAMULU, K., AND DEVREUX, M. 1977. In vitro culture of anthers and stem internodes of Lycopersicum peruvianum: Nuclear DNA determination in calli and cytological analysis of regenerated plants. $Z$. Pflanzenphysiol, , 81, 377-388.

ANDERSON, M. K., TAYLOR, N. L., AND DUNCAN, J. F. 1974. Self-incompatibility, genotype identification and stability as influenced by inbreeding in red clover (Trifolium pratense L.). Euphytica, 23, 140-148.

BARBIER, M., AND DULIEU, H. L. 1980. Effets génétiques observés sur des plantes de Tabac régénérées à partir de cotylédons par culture in vitro. Ann. Amélior. Plant., 30, 321-344.

BREWBAKER, J. L., AND NATARAJAN, A. T. 1960. Centric fragments and pollen-part mutation of incompatibility alleles in Petunia. Genetics, 45, 699-704.

CAPPADOCIA, M., AND SREE RAMULU, K. 1981. Plant regeneration from in vitro cultures of anthers and stem internodes in an interspecific hybrid, Lycopersicon esculentum $\mathrm{L} . \times L$. peruvianum Mill. and cytogenetic analysis of the regenerated plants. Plant Sci. Lett., 20, $157-166$.

CUMMings, D. P., GReEN, C. E., AND STUTH AMAN, D. D. 1976. Callus induction and plant regeneration in oats. Crop $S c i, 16,465-470$.

D'AMATO, F. 1975. The problem of genetic stability in plant tissue and cell cultures. In Crop Genetic Resources for Today and Tomorrow, Intern. Biol. Progr., 2, 333-348.

D'AMATO, F. 1977. Cytogenetics of differentiation in tissue and cell cultures. In Reinert, J., and Bajaj, Y. P. S. (eds.) Applied and Fundamental Aspects of Plant Cells, Tissue and Organ Culture, Springer-Verlag, Berlin, pp. 343-356.

D'AMATO, F. 1978. Chromosome number variation in cultured cells and regenerated plants. In Thorpe, T. A. (ed.) Frontiers of Plant Tissue Culture 1978 Intern. Ass. Plant Tissue Culture, Calgary, pp, 287-295.

DENWARD, T. 1963. The function of the incompatibilty alleles in red clover (Trifolium pratense L.). Hereditas, 49, 189-334.

DEVREUX, M., LANERI, U., AND DE MARTINIS, P. 1975. Réflexions sur nos cultures d'anthères de plantes cultivées. Giorn. Bot. Ital., 109, 335-349.

FISHER, R. A. 1961. A model for the generation of self-sterility alleles. $J$. Theoret. Biol., 1, 411-414.

GASTEL, A. J. G. VAN, AND NETTANCOURT, D. DE, 1974. The effects of different mutagens on self-incompatibility in Nicotiana alata (Link and Otto). I. Chronic gamma irradiation. Radiat. Bot., 14, 43-50.

GASTEL, A. J. G. VAN, AND NETTANCOURT, D. DE, 1975. The effects of different mutagens on self-incompatibility in Nicotiana alata (Link and Otto). II. Acute irradiations with $\mathrm{X}$-rays and fast neutrons. Heredity, 34, 381-392.

GENGENBACH, B. G., CONNELLY, J. A., PRING, D. R., AND CONDE, M. F. 1981. Mitochondrial DNA variation in maize plants regenerated during tissue culture selection. Theoret, Appl. Genet., 59, 161-167.

GUNTHER, E., HERRMANN, H., AND HOFFMANN, M. 1968. Untersuchungen zur Selbstinkompatibilität bei Lycopersicum peruvianum (L.) Mill. Biol. Zbl., 87, 471-479.

HOFFMANN, M. 1971. Induktion und Analyse von selbstkompatiblen Mutanten bei Lycopersicon peruvianum (L.) Mill. II. Analyse der selbstkompatiblen Mutanten. Biol. Zentrabl., 90, 33-41.

HOGENBOOM, N. G., 1972. Breaking breeding barriers in Lycopersicon. 2. Breakdown of self-incompatibility in L. peruvianum (L.) Mill. Euphytica, 21, 228-243.

LAMM, R. 1950. Self-incompatibility in Lycopersicum peruvianum Mill. Hereditas (Lund), $36,509-511$.

LARKIN, P. J., AND SCOWCROFT, W. R. 1981. Somaclonal variation-a novel source of variability from cell cultures. Theoret. Appl. Genet., 60, 197-214.

LEWIS, D. 1949. Structure of the incompatibility gene. II. Induced mutation rate. Heredity, 3, 339-355.

LEWIS, D. 1951. Structure of the incompatibility gene III. Types of spontaneous and induced mutation. Heredity, 5, 399-414.

LEWIS, D. 1958. Gene control of specificity and activity: Loss by mutation and restoration by complementation. Nature, 182, 1620-1621.

LEWIS, D. 1960, Genetic control of specificity and activity of the S-antigen in plants. Proc. Roy. Soc. London, B, 151, 468-477. 
LEWIS, D. 1962. The generation of self-incompatibility alleles. J. Theoret. Biol., 2, 69-71.

LEWIS, D., AND CROWE, L. K. 1954. Structure of the incompatibility gene, IV. Types of mutation in Prunus avium L. Heredity, 8, 357-363.

LUNDQVIST, A. 1965. The genetics of incompatibility. Proc. 11 th Intern. Congr. Genet. The Hague, 1973. In Geerts, S. J. (ed.) Genetics Today, 3, 637-647.

MARTIN, F, W. 1958. Staining and observing pollen tubes in the style by means of fluorescence. Stain Technol., 34, 124-128.

MCGUIRE, D. C., AND RICK, C. M. 1954. Self-incompatibility in species of Lycopersicon sect. Eriopersicon and hybrids with L. esculentum. Hilgardia, 23, 101-124.

MOUSSEAU, J. 1970. Fluctuations induites par la néoformation de bourgeons in vitro. In Cultures des Tissues de Plantes. Strasbourg Coll. Intern. CNRS 293, 234-239.

NETTANCOURT, D. DE 1977. Incompatibility in angiosperms. In Frankel, R., Gall, G. A. E., and Linskens, H. F. (eds.) Theoretical and Applied Genetics 3, Springer-Verlag, Berlin.

NETTANCOURT, D. DE, AND ECOCHARD, R. 1968. Effects of chronic irradiation upon a self-incompatible clone of Lycopersicum peruvianum. Theoret. Appl. Genet., 38, 289-293.

NETTANCOURT, D. DE, AND ECOCHARD, R. 1969. New incompatibility specificities in the $\mathrm{M}_{3}$ progeny of a clonal population of L. peruvianum. Rep. Tomato Genetics Cooperative (Dept. Vegetable Crops. Univ. California, Davis, California) 19, 16-17.

NETTANCOURT, D. DE, ECOCHARD, R., PERQUIN, M. D. G., VAN DER DRIFT, T. AND WESTERHOF, M. 1971. The generation of new $S$-alleles at the incompatibility locus of L. peruvianum Mill. Theor. Appl. Genet., 41, 120-129.

NETTANCOURT, D. DE, DEVREUX, M., CARLUCCIO, F., LANERI, U., CRESTI, M., PACINI, E., SARFATTI, G., AND VAN GASTEL, A. J. G. 1975. Facts and hypotheses on the origin of S-mutations and on the function of S-gene in Nicotiana alata and Lycopersicum peruvianum. Proc. R. Soc. Lond. B, 188, 345-360.

OOMO, K. 1978. High frequency of mutations in rice plants regenerated from seed callus. Abstr. 4th Intern. Congr. Plant Tissue and Cell Culture, Calgary, No. 1607.

PANDEY, K. K. 1956. Mutations of self-incompatibility alleles in Trifolium pratense and $T$. repens. Genetics, 41, 327-343.

PANDEY, K. K. 1965. Centric chromosome fragments and pollen-part mutation of the incompatibility gene in Nicotiana alata Nature, Lond. 2061, 792-795.

PANDEY, K. K. 1970a. Elements of the S-gene complex. VI. Mutations of the self-incompatibility gene, pseudo-compatibility and origin of new incompatibility alleles. Genetica, 41 , 477-516.

PANDEY, K. K. 1970b. New self-incompatibility alleles produced through inbreeding. Nature (London), 227, 689-690.

PANDEY, K. K. 1972. Origin of genetic variation: Regulation of genetic recombination in the higher organisms-a theory. Theoret. Appl. Genet., 42, 250-261.

PANDEY, K. K. 1977. Generation of multiple genetic specificaties: Origin of genetic polymorphism through regulation. Thero. Appl. Genet., 49, 85-93.

POPCHRISTOV, V. D., AND ZAGANSKA, N. A. 1977. Study of the seed progeny of regenerated plants obtained by the tissue culture of tobacco. In Uses of Plant Tissue Cultures in Breeding, Ustav Experimentalni Botaniky CSA V, Prague, pp. 209-221.

SKIRVIN, R. M. 1978. Natural and induced variation in tissue culture, Euphytica, 27, 241-266.

SREE RAMULU, K. 1980. Failure of EMS to induce S-locus mutations in Nicotiana alata Link and Otto. Environ. Expt. Bot. 20, 149-155.

SREE RAMULU, K. 1982. Failure of obligate inbreeding to produce new S-alleles in Lycopersicon peruvianum Mill. Incompatibility Newslett. 14, 103-110.

SREE RAMUlU, K., DEVREUX, M., ANCORA, G. AND LANERI, U. 1976a. Chimerism in Lycopersicum peruvianum plants regenerated from in vitro cultures of anthers and stem internodes. Z. Pflanzenzuichtg., 76, 299-319.

SREE RAMULU, K., DEVREUX, M. AND DE MARTINIS, P. 1976 b. Origin and genetic analysis of plants regenerated in vitro from periclinal chimeras of Lycopersicum peruvianum. $Z$. Pflınzenzüchtg., 77, 116-124.

SREE RAMUlU, K., CARLUCCIO, F., NETTANCOURT DE, D., AND DEVREUX, M. 1977. Trisomics from triploid-diploid crosses in self-incompatible Lycopersicum peruvianum. I. Essential features of aneuploids and of self-compatible trisomics. Theoret. Appl. Genet. 50, 105-119.

SUNDERLAND, N. 1977. Nuclear cytoiogy. In Street, H. E. (ed.) Plant Cell and Tissue Culture, Vol. 2, University of California Press, Berkeley, California, pp. 177-206.

THOMAS, E., KING, P. J., AND POTRYKUS, I. 1979. Improvement of crop plants via single cells in vitro-an assessment. Z. Pflanzenzücht., 82, 1-30. 